\title{
Aplikasi Autoregressive Integrated Moving Average (ARIMA) untuk Meramalkan Jumlah Demam Berdarah Dengue (DBD) di Puskesmas Mulyorejo
}

\author{
Luluk Nor Kasanah \\ Departemen Biostatistika dan Kependudukan FKM UNAIR \\ Fakultas Kesehatan Masyarakat Universitas Airlangga \\ Jl. Mulyorejo Kampus C Unair Surabaya 60115 \\ Alamat Korespondensi: \\ Luluk Nor Kasanah, E-mail: luluknuur@gmail.com
}

\begin{abstract}
ARIMA was one of a forecasting method of time series if independent variable be ignored, it would use the past and present value as a dependent variable. The accuracy of ARIMA forecasting method was good to produce short-term forecasting. The advantages of ARIMA method than other method was this method didn't require the data pattern so it could be used for all kinds of data pattern, so it could be applied in cases of dengue hemorrhagic fever (DHF) in Mulyorejo Public Health Center. This study was to determine the best forecasting model as well as to predict and analyze the results of forecasting number of dengue hemorrhagic fever in Mulyorejo Public Health Center. The data was monthly number of dengue hemorrhagic fever patients in Mulyorejo Public Health Center from January 2010 to February 2016 (a total of 74 plots data). The results were the number of dengue hemorrhagic fever cases in Mulyorejo Public Health Center could be predicted with ARIMA model (1,0,0), thought based on diagnostics test the ARIMA model met all tests but the forecasting number of dengue hemorrhagic fever cases in years 2016-2017 showed a downward trend, and in 2017 was flat, while MAPE and MAE amounted to $63.026 \%$ and 1.89\%, the value of the error was large enough which indicated that less accurate forecasting. DHF data had a lot of missing data caused big value of MAPE and MAE so must be transformed by series mean method. DHF data was trend and seasonal so winters exponential smoothing with ordinary least square was better than ARIMA to get small error.
\end{abstract}

Keywords: ARIMA, Time series, Dengue Hemorrhagic Fever (DHF)

\begin{abstract}
ABSTRAK
ARIMA merupakan salah satu metode peramalan time series jika variabel independent diabaikan, akan menggunakan nilai masa lalu dan sekarang sebagai variabel dependen. Ketepatan hasil metode peramalan ARIMA baik untuk menghasilkan peramalan jangka pendek. Kelebihan metode ARIMA dibandingkan metode time series yang lain adalah metode ini tidak mensyaratkan adanya suatu pola data tertentu, jadi hampir semua jenis pola data dapat tercakup dalam pemodelannya, sehingga dapat diaplikasikan pada kasus DBD di Puskesmas Mulyorejo. Penelitian ini untuk menentukan model terbaik peramalan ARIMA serta menganalisis hasil peramalan kasus DBD di Puskesmas Mulyorejo. Data yang digunakan adalah data bulanan jumlah penderita DBD di Puskesmas Mulyorejo mulai Januari 2010 sampai Februari 2016 (sebanyak 74 plot data). Hasil menunjukkan jumlah kasus DBD di Puskesmas Mulyorejo dapat diramalkan menggunakan model ARIMA (1,0,0), meskipun berdasarkan uji diagnostik model ARIMA $(1,0,0)$ memenuhi semua uji namun hasil peramalan jumlah kasus DBD pada tahun 20162017 menunjukkan trend menurun serta pada tahun 2017 cenderung flat atau mendatar, sementara MAPE sebesar 63,026\% dan MAE sebesar 1,89\%, nilai kesalahan tersebut cukup besar yang mengindikasikan bahwa peramalan kurang akurat. Data DBD banyak mengandung missing menyebabkan nilai MAPE dan MAE yang besar sehingga harus ditransformasi dengan metode series mean. Data DBD di Puskesmas Mulyorejo merupakan data trend dengan pengaruh musiman maka metode winters exponential smoothing dengan menggunakan ordinary least square lebih baik dibandingkan dengan metode ARIMA untuk mendapatkan nilai kesalahan yang lebih kecil.
\end{abstract}

Kata kunci: ARIMA, Time Series, Demam Berdarah Dengue (DBD) 


\section{PENDAHULUAN}

Banyak jenis metode peramalan yang tersedia. Pemilihan jenis metode tersebut mulai dari metode yang paling sederhana hingga metode yang paling rumit, pemilihan tersebut tergantung pada tipe pola data, faktor yang dapat mempengaruhi hasil peramalan dan berbagai aspek lain. Penggunaan metode peramalan dibagi dalam dua kategori utama, yaitu metode peramalan objektif dan metode peramalan subjektif (judgmental). Pada metode peramalan objektif dibagi dalam deret berkala (time series) dan model regresi (kausal), sedangkan pada metode peramalan subjektif terdiri dari analogies, delphi, PERT dan survey techniques (Makridakis et al., 1999).

Metode time series merupakan salah satu metode peramalan objektif. Metode ini tepat digunakan untuk melakukan peramalan terhadap nilai historis yaitu nilai pada masa yang akan datang berdasarkan nilai pada masa lalu dan sekarang, tanpa memperdulikan mengapa terjadi peningkatan nilai tertentu. Secara sederhana model time series merupakan seperangkat hasil pengamatan kontinyu terhadap suatu variabel yang disusun atau diperoleh berdasarkan rentang waktu yang sama, misalnya tiap jam, tiap hari, tiap minggu ataupun tiap tahun.

Metode ARIMA merupakan salah satu metode peramalan time series yang hanya menggunakan variabel dependen berupa nilai masa lalu dan masa sekarang, sementara variabel independen diabaikan secara penuh.

Alasan metode ARIMA dikembangkan karena metode peramalan yang ada selalu dibatasi dengan asumsi hanya untuk berbagai macam pola tertentu, contohnya adalah metode pemulusan eksponensial (eksponential smoothing) asumsi yang digunakan berupa adanya suatu pola data yang stasioner. Metode ARIMA tidak membutuhkan adanya asumsi tentang suatu pola yang tetap sehingga berbeda dengan metode lainnya (Hermawan, 2011).

Ketepatan hasil peramalan metode ARIMA akan baik jika data dependent yang digunakan memiliki hubungan satu sama lain secara statistik (Wei, 2006). Secara umum, model ARIMA ditulis dengan ARIMA (p,d,q) yang berarti model ARIMA terdiri dari derajat AR (p), derajat pembeda d dan derajat MA (q).
Selain memiliki fungsi peramalan secara kuantitatif berdasarkan deret waktu juga dapat menggambarkan perkembangan suatu kegiatan atau kondisi tertentu (Baroroh, 2013). Kondisi yang digambarkan bersifat umum yang berarti dapat diaplikasikan pada berbagai fenomena berbeda seiring berjalannya waktu termasuk dalam bidang kesehatan masyarakat. Salah satu masalah kesehatan masyarakat yang patut menjadi perhatian adalah Demam Berdarah Dengue (DBD). Data pengamatan jumlah DBD dapat dilihat sebagai data time series. Data tersebut dapat disajikan melalui model ARIMA (p,d,q) dengan melewati proses-proses Autoregressive (AR) dan Moving Average (MA).

DBD merupakan penyakit infeksi dari virus dengue yang ditularkan oleh gigitan nyamuk Aedes Aegypti sebagai vektor, selain itu DBD merupakan salah satu penyakit daerah tropis yang sangat mudah sekali menular. World Health Organization (2013) memperkirakan 2,5 milyar masyarakat dunia memiliki risiko terkena virus dengue dan lebih dari 50-100 juta infeksi dengue di seluruh dunia setiap tahunnya. Infeksi dengue yang berat juga diperkirakan menyerang kurang lebih 500.000 penduduk dunia dan 2,5\% diantaranya meninggal dunia. Jumlah kasus DBD di kawasan Asia Tenggara meningkat dari tahun 2011 sebesar 100.278 kasus menjadi 257.024 kasus di tahun 2012.

Berdasarkan publikasi dari badan kesehatan dunia WHO dalam Dengue Guidelines for Diagnosis, Treatment, Prevention and Control, DBD merupakan masalah kesehatan masyarakat yang besar di Indonesia. Indonesia yang berada di daerah tropis pada daerah ekuator memungkinkan perkembangbiakan Aedes Aegypti yang merupakan vektor dari virus dengue. Pada tahun 2014 jumlah penderita DBD di Indonesia yang telah dilaporkan sebanyak 100.347 kasus dengan jumlah kematian sebanyak 907 jiwa (IR sebesar 39,8 per 100.000 jumlah penduduk dan CFR sebesar 0,9\%) (Depkes RI, 2014).

Berdasarkan data Dinas Kesehatan Provinsi Jawa Timur sampai dengan Juni 2013, telah terjadi 11.207 kejadian DBD dengan Incidency Rate (IR) sebesar 29,25 dan CFR sebesar 0,88\%. Berdasarkan laporan yang sama, di Surabaya Incidency Rate (IR) sebesar 1.504 kasus dengan CFR 0,4\%. Surabaya merupakan kota dengan IR 
DBD tertinggi di Jawa Timur (Dinas Kesehatan Provinsi Jawa Timur, 2013).

Melihat perkembangan kasus DBD di Surabaya serta fakta bahwa di Puskesmas Mulyorejo belum pernah dilakukan peramalan jumlah pasien DBD. Maka perlu suatu metode peramalan untuk meramalkan jumlah penderita DBD pada tahun yang akan datang sebagai langkah preventif untuk mencegah terjadinya peningkatan jumlah pasien DBD di Puskesmas Mulyorejo.

\section{METODE PENELITIAN}

Jenis penelitian yang digunakan pada penelitian ini adalah penelitian non-reaktif (unobstructive) yaitu peneliti tidak memerlukan respons dari subjek penelitian serta peneliti tidak melakukan interaksi terhadap subjek penelitian. Penelitian ini menggunakan data sekunder, data yang digunakan berupa data bulanan jumlah penderita DBD yang tercatat dan dilaporkan di Puskesmas Mulyorejo mulai Januari 2010 sampai Februari 2016 (sebanyak 74 plot titik).

Data yang digunakan pada penelitian ini adalah data rekam medis di Puskesmas Mulyorejo. Hasil yang diperoleh dari pengolahan data kemudian dianalisis pada bagian analisis data. Data dianalisis dengan komputerisasi.

Tujuan dari analisis data adalah memberikan penjelasan mengenai hasil menjadi lebih mudah dimengerti serta dapat ditarik kesimpulan untuk kemudian dapat dirumuskan saran atau rekomendasi.

Langkah-langkah dalam menganalisis data terdiri dari tiga tahap ARIMA yaitu tahap pertama identifikasi model meliputi pemeriksaan stasioneritas data dan identifikasi model sementara. Tahap kedua penaksiran parameter dan pengujian diagnosis meliputi uji kenormalan residual, uji white noise dan uji signifikansi parameter. Tahap ketiga penerapan meliputi penerapan hasil peramalan dan evaluasi.

\section{HASIL PENELITIAN}

Gambaran Jumlah Penderita DBD di Puskesmas Mulyorejo Kota Surabaya

Berdasarkan Gambar 1 diketahui bahwa selama periode Januari 2010 hingga Februari

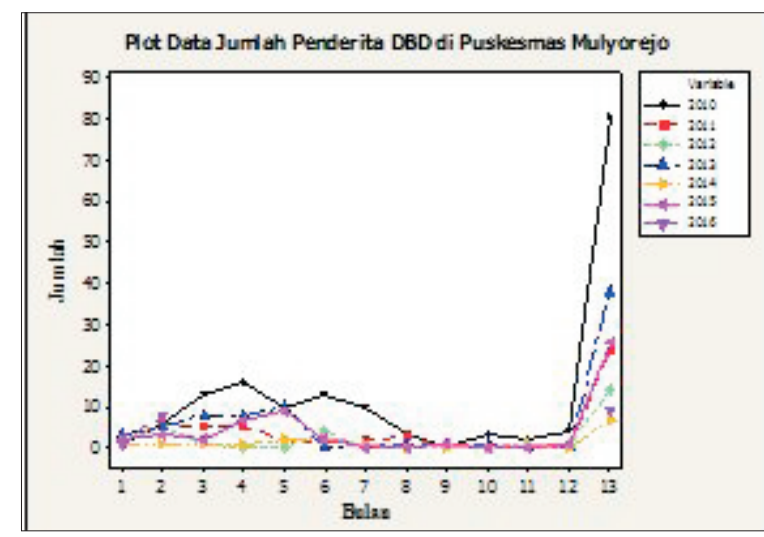

Gambar 1. Plot Data Jumlah Penderita DBD di Puskesmas Mulyorejo.

2016 jumlah kasus DBD di Puskesmas Mulyorejo cenderung mengalami naik turun (fluktuatif).

Pada tahun 2010 ke 2011 mengalami penurunan yang tajam dari 81 kasus menjadi 24 kasus, begitu juga dengan tahun 2011 ke 2012 juga mengalami penurunan meskipun tidak setajam tahun sebelumnya. Akan tetapi pada tahun 2012 ke 2013 mengalami kenaikan kasus dari 14 menjadi 38, kemudian pada tahun 2014 turun menjadi 7 kasus dan kembali naik pada tahun 2015 menjadi 26 kasus.

Berdasarkan tabel 1 jumlah kejadian DBD dibagi menjadi 4 kuartal dengan 1 kuartal terdiri dari 3 bulan. Total kuartal mulai 2010 hingga 2015 secara berturut-turut adalah total kuartal I (Januari-Maret) sebanyak 62 kasus, kuartal II (April-Juni) sebanyak 91, kemudian kuartal III (Juli-September) sebanyak 24 kasus dan kuartal

Tabel 1. Jumlah Kejadian DBD di Puskesmas Mulyorejo Berdasarkan Kuartal Waktu

\begin{tabular}{|c|c|c|c|c|c|}
\hline & Jum & ejac & $\overline{\text { DBI }}$ & uart & \\
\hline Tahun & & & & & Total \\
\hline & I & II & III & IV & \\
\hline 2010 & 20 & 39 & 13 & 9 & 81 \\
\hline 2011 & 11 & 8 & 5 & 0 & 24 \\
\hline 2012 & 7 & 4 & 1 & 2 & 14 \\
\hline 2013 & 16 & 18 & 3 & 1 & 38 \\
\hline 2014 & 1 & 4 & 1 & 1 & 7 \\
\hline 2015 & 7 & 18 & 1 & 0 & 26 \\
\hline Total & 62 & 91 & 24 & 13 & 190 \\
\hline
\end{tabular}


IV (Oktober-Desember) sebanyak 13 kasus. Dari rincian tersebut kasus tertinggi terdapat pada kuartal II dan kasus terendah terjadi pada kuartal IV.

Secara umum kasus tertinggi DBD terjadi pada tahun 2010 dengan total 81 kasus. Sedangkan jika ditinjau dari bulan peningkatan kasus DBD terjadi sepanjang bulan Februari hingga Mei dengan puncak kasus pada bulan April.

\section{Pemeriksaan Stasioneritas Data Kasus DBD di Puskesmas Mulyorejo}

Berdasarkan Gambar 2 plot dan analisis keberadaan tren data time series menunjukkan bahwa data kasus DBD memiliki tren yang cenderung turun. Berdasarkan perhitungan statistik deskriptif didapat nilai means sebesar 2,77. Pada Gambar 2 tersebut terlihat bahwa penyebaran data berdasarkan means terlihat konstan dari waktu ke waktu, tidak terdapat beberapa variasi data naik turun yang tajam. Dengan demikian dapat dikatakan bahwa data telah stasioner dalam means. Nilai varians sebesar 13,056 dan terlihat pada Gambar 2 varians dari tiap titik historis tidak konstan setiap waktu

Pada gambar 3 plot box-cox menunjukkan nilai rounded value atau lambda bernilai $-1,00$, nilai tersebut kurang dari 1 sehingga data tidak stasioner dalam varians sehingga perlu dilakukan transformasi logaritma. Setelah dilakukan proses transformasi maka data telah stasioner dalam means dan varians.

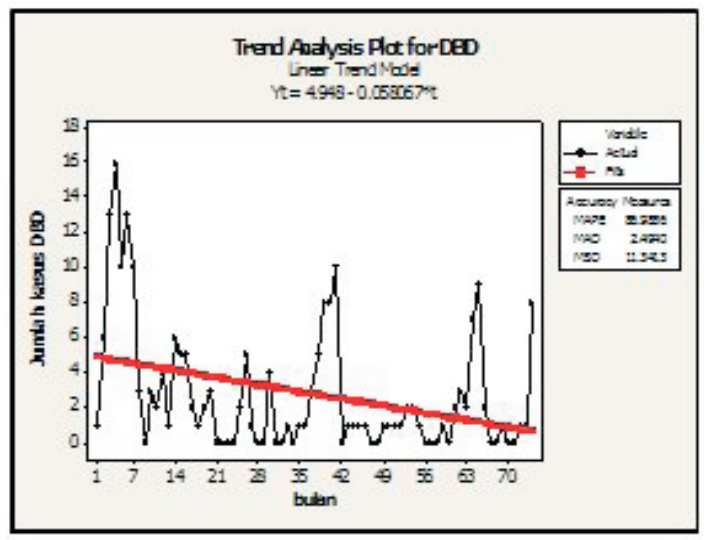

Gambar 2. Data Kasus DBD di Puskemas Mulyorejo.

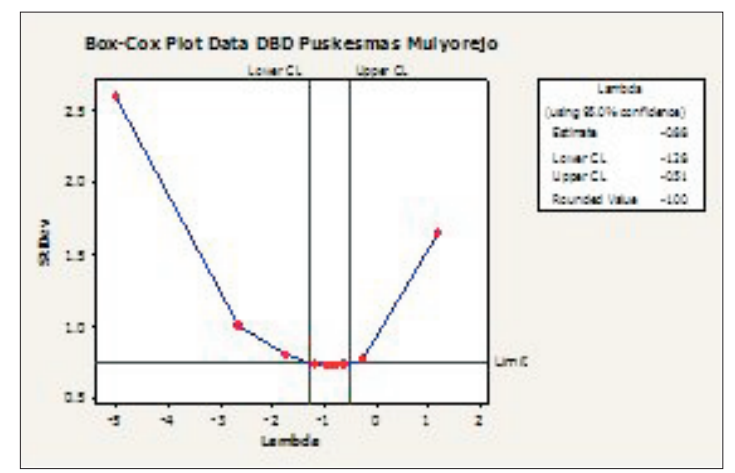

Gambar 3. Box- Cox Plot Jumlah Penderita DBD di Puskesmas Mulyorejo.

\section{Identifikasi Model Sementara (Tentative)}

Identifikasi model dengan menentukan model sementara pada orde p,d,q. Cara menentukan orde $\mathrm{p}$ dan $\mathrm{q}$ dengan melihat plot pola fungsi autokorelasi (ACF) dan fungsi autokorelasi parsial (PACF) sedangkan orde d berdasarkan pada proses differencing.

Dari gambar 4 dapat dilihat pada plot pola ACF Berbentuk sinusoidal (menurun secara bertahap menuju ke-0) sehingga dugaan pada aspek MA $=0$.

Pada gambar 5 plot PACF menuju ke- 0 setelah lag ke 1, maka dugaan model sementara adalah AR (1). sedangkan pada plotting data sebelumnya tidak dilakukan proses differencing maka orde $d$ adalah 0 , sehingga dugaan model sementara adalah ARMA $(1,0,0)$.

\section{Estimasi Parameter Model}

Setelah model sementara diperoleh yaitu ARIMA $(1,0,0)$ maka tahap berikutnya ialah menentukan besarnya nilai parameter model,

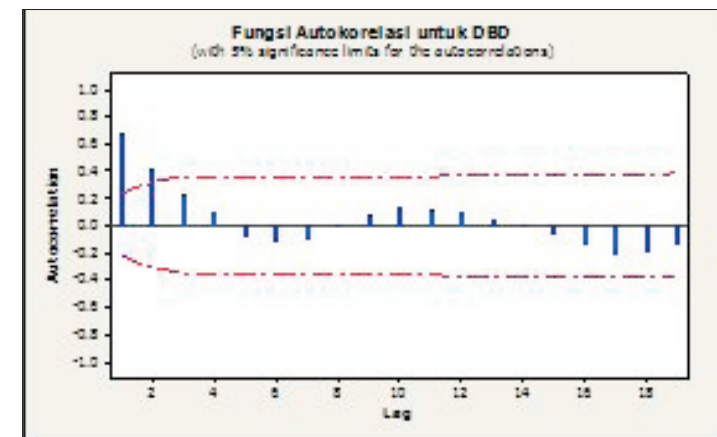

Gambar 4. Plot PolaACF dengan Transformasi Log tanpa Proses Differencing. 


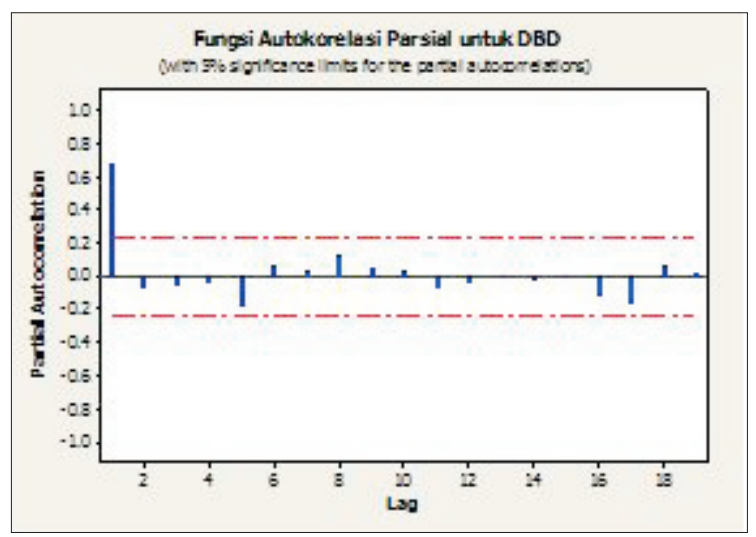

Gambar 5. Plot Pola PACF dengan Transformasi Log tanpa Proses Differencing.

yaitu besarnya koefisien Autoregressive $(\varphi)$ dan koefisien Moving Average $(\theta)$, sehingga dapat dirumuskan persamaan yang utuh terhadap model tersebut.

Berdasarkan Tabel 2 diketahui bahwa pengujian parameter telah memenuhi batasan, yaitu Nilai t hitung pada constant dan $\mathrm{AR}_{1}=$ $-2<\varphi_{1}<2$, di mana parameter constant sebesar 0,8837 dan parameter $\varphi_{1}$ sebesar 0,6920. Koefisien yang dimasukkan dalam persamaan adalah yang signifikan terhadap model dengan syarat $\mid \mathrm{t}$ hitung $\mid>\mathrm{t}$ tabel, di mana $\mathrm{t}$ tabel bernilai 1,993 .

Berdasarkan hasil pengestimasian parameter pada Tabel 2 dapat ketahui bahwa:

Nilai consant memiliki nilai t hitung sebesar 2,85, Karena 2,85>1,993 maka parameter 0,8837 signifikan pada alfa $5 \%$.

Nilai $\mathrm{AR}_{1}$ memiliki nilai t hitung sebesar 7,91, Karena 7,91>1,993 maka parameter $\varphi_{1}=0,6920$ signifikan pada alfa 5\%. Maka syarat estimasi parameter sudah terpenuhi.

Tabel 2. Estimasi Parameter Model ARIMA $(1,0,0)$

\begin{tabular}{lcccc}
\hline \multicolumn{1}{c}{ Tipe } & Koefisien & $\begin{array}{c}\text { SE } \\
\text { Coef }\end{array}$ & T & $\begin{array}{c}\boldsymbol{P} \\
\text { Value }\end{array}$ \\
\hline $\mathrm{AR}_{1}$ & 0,6920 & 0,087 & 7,91 & 0,000 \\
Constant & 0,8837 & 0,310 & 2,85 & 0,006 \\
Rata-rata & 2,869 & 1,006 & & \\
\hline
\end{tabular}

\section{Pemeriksaan Diagnostik}

Pemeriksaan diagnostik untuk membuktikan bahwa model tersebut sudah baik untuk digunakan. Pada pemeriksaan terhadap model, terdapat beberapa uji kesesuaian model yang bisa dilakukan, antara lain uji kenormalan residual, uji white noise, uji signifikansi parameter.

Tabel 3 menunjukkan uji Kenormalan Residual dengan menggunakan uji statistik Kolmogorov-Smirnov dengan hipotesis yang diuji adalah residual berdistribusi normal $\left(\mathrm{H}_{0}\right.$ diterima).

Dari tabel 3 dapat dilihat bahwa nilai $p$-value adalah $0,070>$ alfa 0,05 sehingga $\mathrm{H}_{0}$ diterima yang berarti memenuhi syarat residual bersifat normal. Uji kesesuaian yang kedua adalah uji White Noise, jika nilai error bersifat random maka suatu model dikatakan baik, dimana proses menunjukkan tidak ada korelasi serial (no autocorrelation), dengan kata lain bahwa residual sudah tidak mempunyai pola tertentu lagi atau bersifat acak $($ means $=0$ dan varians $=$ konstan).

Cara untuk melihat white-noise dengan menggunakan salah satu dari dua statistik uji yaitu Uji $Q$ Box-Pierce dan statistik uji Ljung-Box. Model Box-Jenkins dikatakan baik jika residual telah bersifat White noise $\left(\mathrm{H}_{0}\right.$ diterima).

Dari hasil output tabel 4. menunjukkan nilai signifikansi Ljung-Box $Q$ adalah 0,849 > alfa 0,05 sehingga $\mathrm{H}_{0}$ diterima artinya memenuhi syarat residual bersifat white noise.

Uji signifikansi parameter model dilakukan untuk mengetahui layak tidaknya parameter tersebut digunakan dalam model dengan menggunakan statistik uji t. Statistik uji t digunakan untuk melihat apakah model secara individu berbeda dengan nol.

Tabel 3. Hail Uji Normalitas Residual ARIMA $(1,0,0)$

\begin{tabular}{lcc}
\hline \multicolumn{2}{c}{ Satu Sampel Kolmogorov-Smirnov } \\
\hline \multirow{2}{*}{$\mathbf{N}$} & \multicolumn{2}{c}{ Residual ARIMA $\mathbf{( 1 , 0 , 0 )}$} \\
\cline { 2 - 3 } & & $\mathbf{7 4}$ \\
\hline Parameter & Rata-rata & 0,02 \\
& Std. Deviasi & 2,710 \\
Kolmogorov-Smirnov Z & 1,294 \\
Asymp. Sig (2 arah) & 0,070 \\
\hline
\end{tabular}


Tabel 4. Uji White Noise ARIMA $(1,0,0)$

\begin{tabular}{crccc}
\hline Model & \multicolumn{3}{c}{ Model fit statistik } & $\begin{array}{c}\text { Ljung- } \\
\text { Box } \boldsymbol{Q}\end{array}$ \\
\cline { 2 - 5 } ARIMA & $\mathbf{R}^{\mathbf{2}}$ & MAE & MaxAE & Sig. \\
\hline$(1,0,0)$ & 0,453 & 1,956 & 8,043 & 0,849 \\
\hline
\end{tabular}

Berdasarkan tabel 2 dapat dilihat nilai signifikan dari parameter $\mathrm{AR}_{1}$ dan konstan adalah 0,0001 dan $0,006<$ alfa $(0,05)$ sehingga $\mathrm{H}_{0}$ ditolak artinya secara individu parameter berbeda dengan nol, dengan kata lain parameter hasil peramalan layak untuk digunakan.

Secara keseluruhan model ARIMA $(1,0,0)$ telah memenuhi hasil pengujian diagnosis, maka model layak untuk digunakan.

\section{Penggunaan Model Terbaik untuk Peramalan}

Tahap terakhir dalam peramalan menggunakan metode ARIMA adalah forecasting dengan persamaan yang telah diperoleh serta telah memenuhi uji kelayakannya. Persamaan peramalan yang akan digunakan untuk memproyeksikan jumlah kasus DBD tahun 2016-2017 di Puskesmas Mulyorejo, dengan persamaan model ARIMA $(1,0,0)$, yakni:

$$
(1-0,6920 B) X_{t}=0,8837+e_{t}
$$

Gambar 6 menunjukkan data time series kasus DBD serta hasil peramalan mulai Maret 2016 sampai Desember 2017 dengan confidence limit 95\%. Kemudian hasil tersebut dievaluasi dengan menggunakan accuracy measures MPE (Mean Percentage Error) dan MAPE (Mean Absolute Percentage Error). Data yang digunakan untuk mendapatkan nilai MPE dan MAPE sebanyak 12 titik data historis, yakni data bulan Januari-Desember 2015.

Berdasarkan output di peroleh nilai MAPE sebesar $63,026 \%$ dan MAE 1,89\% yang berarti bahwa jika melakukan peramalan sebanyak 12 periode ke depan, maka terdapat kesalahan 1,89\% dan kesalahan absolut sebesar $63,026 \%$. Nilai MAPE dan MAE yang besar mengindikasikan bahwa hasil peramalan kurang akurat.

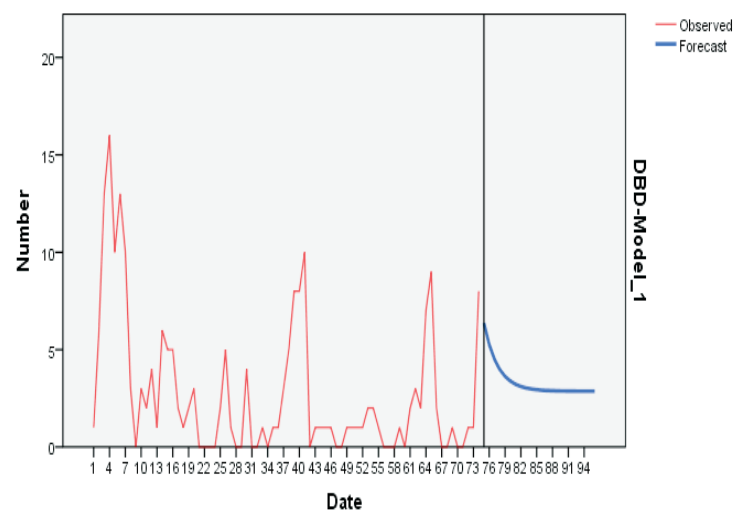

Gambar 6. Plot Kasus DBD tahun 2010-2015 dan Hasil Peramalan 2016-2017.

\section{PEMBAHASAN}

\section{Gambaran Umum Kasus Demam Berdarah Dengue di Puskesmas Mulyorejo}

Trend Demam Berdarah Dengue (DBD) di Puskesmas Mulyorejo berdasarkan waktu memperlihatkan jika peningkatan kasus DBD di mulai pada bulan Desember hingga bulan Mei (pada awal musim hujan) dengan puncak kasus pada bulan Februari dan April. Hal ini disebabkan pada musim hujan jumlah sarang nyamuk di luar meningkat sehingga vektor penyakit demam berdarah populasinya juga meningkat sebagai akibat buruknya sistem sanitasi lingkungan. Lebih lanjut menurut Departemen Kesehatan RI, tempat penampungan air yang banyak digunakan oleh masyarakat adalah bak mandi, ember, drum, tangki air, tempat gelas pada dispenser, tempat minum burung, pot bunga, tempat pembuangan air kulkas, bak kontrol pembuangan air, barangbarang bekas dan tempat penampungan air alamiah seperti lubang pohon (Depkes RI, 2011).

Pada umumnya bak mandi yang digunakan oleh penduduk Indonesia terbuat dari semen. Dinding bak mandi yang terbuat dari semen tersebut memiliki tekstur kasar, mudah menyerap air, dan gelap. Dinding tempat penampungan air seperti itu sangat disukai Aedes Aegypti. (Sungkar, 2007).

Jumlah kasus DBD ditinjau dari kuartal waktu pada tabel 1 memperlihatkan secara umum jumlah kasus DBD tertinggi terjadi pada kuartal 
II (Bulan April-Juni) dengan kasus sebanyak $91(48 \%)$ dan terendah terjadi pada kuartal IV (Bulan Oktober-Desember) sebanyak 13 (7\%).

Berdasarkan laporan curah hujan di Stasiun Perak I (Surabaya Utara) yang di publis oleh BPS Kota Surabaya sejak tahun 2010-2014 menunjukkan jika rata-rata curah hujan tertinggi terjadi pada kuartal I yaitu pada bulan Januari. Sedangkan curah hujan terendah terjadi pada kuartal III yaitu pada bulan Agustus dan September. Berdasarkan informasi tersebut dapat dilihat bahwa jika pada curah hujan yang tinggi adalah awal bertambahnya kasus DBD sehingga pada bulan pergantian musim dan hujan harian yang cenderung rendah (kuartal II) justru terjadi peningkatan kasus. Hal ini disebabkan kehidupan nyamuk dapat dipengaruhi hujan dengan 2 cara, yaitu menyebabkan naiknya kelembaban nisbi udara dan menambah tempat perindukan. Setiap $1 \mathrm{~mm}$ curah hujan meningkatkan kepadatan nyamuk 1 ekor, akan tetapi larva akan hanyut dan mati apabila curah hujan dalam seminggu sebesar $140 \mathrm{~mm}$ (Suroso, 2011).

Jumlah penderita DBD di Puskesmas Mulyorejo menunjukkan trend penurunan kasus pada tahun 2011, 2012, 2014, dan 2015 dengan penurunan terbanyak pada tahun 2014 yaitu $-6,1667$. Jika dilihat dari faktor kelembaban berdasarkan data dari BPS Kota Surabaya Stasiun Pantau Perak I menunjukkan rata-rata kelembaban di Kota Surabaya Utara tahun 2010-2015 sebesar 73\% dengan nilai kelembaban tertinggi terjadi pada tahun 2015 dan 2013 yaitu $78 \%$ dan $76 \%$ dan terendah pada tahun 2012 dan 2014 yaitu $70 \%$ dan $73 \%$.

Hal tersebut menunjukkan bahwa perubahan kelembaban selama periode 20102015 berbanding lurus dengan pengaruh tahunan DBD di Puskesmas Mulyorejo. Hal tersebut dikarenakan sistem pernafasan nyamuk menggunakan pipa udara dengan lubang-lubang pada dinding tubuh nyamuk (spiracle). adanya spiracle yang terbuka lebar tanpa ada mekanisme pengaturannya. Pada saat kelembaban rendah mempengaruhi penguapan air dari dalam tubuh sehingga menyebabkan keringnya cairan dalam tubuh nyamuk. Kelembaban mempengaruhi umur nyamuk, jarak terbang, kecepatan berkembang biak, kebiasaan menggigit dan istirahat (Wirayoga, 2013).
Penurunan kasus DBD di Puskesmas Mulyorejo selain karena pengaruh aspek cuaca, curah hujan dan kelembaban udara yang merupakan faktor alam yang tidak bisa dikendalikan, aspek lain yang ikut berperan yaitu karena berdasarkan hasil penyelidikan epidemiologi yang dilakukan petugas Puskesmas bahwa sebagian besar kasus DBD terjadi pada wilayah endemis yaitu beberapa kawasan elit seperti Mulyosari, Dharma Husada Indah, Wisma Permai dan Perumahan Bhaskara.

Hal tersebut menjelaskan mengapa pada daerah Kejawen Putih Tambak (KPT) memiliki kasus yang rendah setiap tahun bila dibandingkan dengan Kelurahan yang lain meskipun ratarata angka bebas jentik di KPT paling rendah yaitu hanya $85 \%$. Sebab jika wilayah tersebut jumlah penderita DBD semakin banyak maka di wilayah tersebut orang yang di dalam darahnya mengandung virus dengue juga semakin banyak. Sehingga apabila nyamuk AA yang sebelumnya tidak mengandung virus dengue, kemudian menggigit orang sakit DBD atau carier DBD maka virus tersebut akan memperbanyak diri dan menyebar ke seluruh tubuh nyamuk, termasuk ke kelenjar liurnya dan nyamuk tersebut seumur hidup dapat menularkan virus dengue ke orang sehat. Serta pada keturunan nyamuk berikutnya secara alami telah mewariskan virus dengue (Depkes RI, 2011).

\section{Peramalan Kasus Demam Berdarah Dengue di Puskesmas Mulyorejo}

ARIMA merupakan salah satu metode peramalan time series yang secara penuh mengabaikan variabel independent dengan hanya menggunakan variabel waktu sebagai variabel dependen. Sebuah model runtun waktu digunakan berdasarkan ketentuan bahwa data yang digunakan harus stasioner, artinya ratarata (means) dan variasi data (varians) bersifat konstan. Tetapi hal ini tidak banyak ditemui pada beberapa data time series yang ada, karena data time series yang ada mayoritas merupakan data yang tidak stasioner melainkan integrated (Aritonang, 2009).

Peramalan jumlah kasus DBD di Puskesmas Mulyorejo Surabaya menggunakan analisis time series ARIMA. Metode ARIMA menganalisis data yang sudah stasioner dalam varians dan 
means. Penggunaan metode ARIMA untuk peramalan jumlah kasus DBD di Puskesmas Mulyorejo pada tahun 2016-2017 dikarenakan metode ini dapat diaplikasikan pada semua pola data dan lebih akurat dibandingkan dengan metode peramalan time series univariabel lainnya.

Pola data DBD apabila dilihat dengan menggunakan plot time series pada gambar 1 Menunjukkan bahwa data tersebut cenderung naik turun terdapat beberapa titik yang kenaikan dan penurunannya terlihat secara tajam, tetapi dilihat dari trend cenderung turun.

Berdasarkan pemeriksaan stasioneritas data Plot data time series jumlah kasus DBD di Puskesmas Mulyorejo bulan Januari 2010 sampai Februari 2016 menunjukkan bahwa data tersebut fluktuatif serta pada data tidak terdapat pertumbuhan atau penurunan secara tajam. Data secara kasarnya horizontal mengikuti sumbu waktu, terlihat persebaran data berada di sekitar nilai rata-rata yang tetap, tidak tergantung pada waktu dan varians dari tiap titik historis tetap konstan setiap waktu sehingga data sudah stasioner means, tetapi berdasarkan plot boxcox pada gambar 3 memperlihatkan data belum stasioner dalam varians karena nilai rounded value $<1$ sehingga perlu dilakukan transformasi logaritma.

Tahap identifikasi model sementara ARIMA untuk menentukan ordo Autoregressive $(p)$ dan Moving Average ( $q$ ) dengan cara melihat nilai ACF dan PACF dari data jumlah kasus DBD di Puskesmas Mulyorejo yang telah stasioner.

Berdasarkan gambar 4 dan 5 Plot ACF terlihat bahwa berbentuk sinusoidal yaitu penurunan data secara bertahap menuju ke-0 dan plot pola PACF menunjukkan nilai cuts off terletak pada lag 1 sehingga diperkirakan model yang terbentuk terdapat AR. Data tidak mengalami proses diferensiasi sehingga $d$ bernilai 0 . Berdasarkan identifikasi pola ACF dan PACF tersebut maka model ARIMA sementara yang terbentuk dari data jumlah kasus DBD di Puskesmas Mulyorejo adalah ARIMA $(1,0,0)$.

Model ARIMA $(1,0,0)$ memiliki 1 parameter yaitu AR $(p=1)$. Menurut Aristonang (2009), model masih dapat digunakan meskipun hasil estimasi parameter menunjukkan bahwa koefisien AR atau MA signifikan, tetapi konstanta tidak signifikan.

Tahap pemeriksaan diagnosis untuk memeriksa bahwa model yang terbentuk memadai. Suatu model dikatakan baik dan layak digunakan dalam peramalan jika ketiga uji asumsi model tersebut bisa terpenuhi yaitu uji normalitas residual, uji signifikansi parameter model, dan uji white noise pada residual (Aristonang, 2009).

Dari tabel 3 dapat dilihat bahwa nilai $p$-value adalah $0,070>$ alfa 0,05 sehingga $\mathrm{H}_{0}$ diterima yang berarti memenuhi syarat residual bersifat normal.

Dari hasil output tabel 4 dapat dilihat jika nilai signifikansi Ljung-Box Q adalah 0,849> alfa 0,05 sehingga $\mathrm{H}_{0}$ diterima artinya memenuhi syarat residual bersifat white noise yaitu error bersifat acak yang menunjukkan tidak ada autocorrelation.

Berdasarkan tabel 2 dapat dilihat nilai signifikan pada aspek constant dan $\mathrm{AR}_{1}$ adalah 0,0001 dan $0,006<$ alfa $(0,05)$ sehingga $\mathrm{H}_{0}$ ditolak artinya koefisien model secara individu berbeda dengan nol, dengan kata lain parameter hasil peramalan layak untuk digunakan.

Dari pemeriksaan diagnosis diatas ketiga uji terpenuhi sehingga model dikatakan layak untuk digunakan.

Gambar 6 merupakan plot data jumlah hasil peramalan dengan tingkat kepercayaan 95\%. Hasil peramalan pada Januari sampai Desember 2017 menunjukkan trend turun meskipun pada plot ke-80 relatif datar.

Makridakis et al., (1999) mengatakan bahwa dalam banyak situasi peramalan, ketepatan dianggap sebagai kriteria penolakan dalam memilih suatu metode peramalan. Berdasarkan gambar 6 dapat diketahui adanya perbedaan antara hasil peramalan dengan data aktual. Hasil peramalan menunjukkan angka yang lebih tinggi bila dibandingkan dengan data aktual. Tetapi jika dilihat dari plot bulan maka data peramalan tidak berbeda jauh di mana terjadi peningkatan kasus pada bulan desember hingga bulan juni artinya pola tersebut menunjukkan jika kasus DBD meningkat seiring pergantian musim yaitu memasuki musim hujan dan pergantian musim hujan ke kemarau. 


\section{Pentingnya Peramalan Jumlah Kasus DBD di Puskesmas Mulyorejo pada Tahun 2016-2017}

Surabaya sebagai daerah endemis DBD dengan kondisi kepadatan penduduk yang tinggi dan arus mobilisasi yang tinggi dibandingkan dengan wilayah lain di Jawa Timur menjadikan Surabaya sangat rentan mengalami lonjakan kasus tiap tahun.

Meskipun pada awal tahun 2016 surabaya berhasil menurunkan angka kejadian DBD dibandingkan tahun 2015 tetapi tetap perlu adanya perencanaan program yang bagus agar setiap tahun dapat menekan angka kejadian DBD di Kota Surabaya termasuk diantaranya Puskesmas Mulyorejo.

Hasil peramalan yang diperoleh dapat memberikan masukan kepada pihak Dinas Kesehatan Kota Surabaya untuk dilanjutkan ke Puskesmas mengenai pembuatan kebijakan program dan merencanakan kebutuhan sumber daya untuk melakukan upaya antisipasi baik secara promotif maupun preventif terhadap terjadinya kejadian DBD di Surabaya khususnya Puskesmas Mulyorejo. Hal ini dikarenakan adanya peningkatan jumlah kasus DBD tersebut menimbulkan berbagai masalah yang harus dihadapi baik oleh penderita, masyarakat, pihak Puskesmas dan pihak Pemerintah terkait. Pihak Puskesmas sebagai garda terdepan kesehatan masyarakat dapat meminimalkan kejadian DBD melalui pengoptimalan kegiatan PJB (Pemeriksaan Jentik Berkala) setiap hari jumat agar semua kawasan dapat tercakup tidak terkecuali pada beberapa kawasan elit.

\section{SIMPULAN DAN SARAN}

\section{Simpulan}

Model ARIMA yang dapat digunakan untuk meramalkan jumlah penderita DBD di Puseksmas Mulyorejo adalah ARIMA $(1,0,0)$ dengan persamaan sebagai berikut:

$(1-0,6920 B) X_{t}=0,8837+e_{t}$
Model tersebut memenuhi semua asumsi pengujian diagnostik sehingga dapat digunakan.

Hasil peramalan jumlah kasus DBD di Puskesmas Mulyorejo tahun 2016-2017 menunjukkan trend menurun jika dibandingkan data aktual tahun sebelumnya. Hasil peramalan memberikan nilai MAPE sebesar 63,026\% dan MAE sebesar 1,89\%, nilai kesalahan tersebut cukup besar yang mengindikasikan bahwa peramalan kurang akurat. Kurang akuratnya peramalan dikarenakan data yang dipakai adalah data Puskesmas sehingga jumlah data kecil dan memungkinkan banyak bulan yang memiliki jumlah 0 .

\section{Saran}

Saran untuk peneliti yang lain yaitu untuk menghasilkan peramalan yang lebih akurat sebaiknya menggunakan data yang lengkap dan menghindari data yang mengandung banyak missing data yaitu dengan memanfaatkan data dengan lingkup yang lebih luas atau dapat dilakukan dengan mentransformasi data missing dengan metode series mean.

Masukan kepada pihak Puskesmas untuk mengoptimalkan kegiatan PJB (Pemeriksaan Jentik Berkala) setiap hari jumat terutama saat memasuki musim hujan dan pergantian musim hujan ke kemarau, khususnya pada daerah endemis dan daerah dengan angka bebas jentik (ABJ) yang rendah dengan cara memberikan edukasi dan pendampingan kepada kader bumantik oleh petugas sanitasi di Puskesmas secara rutin serta memberikan penyuluhan dan menggerakkan masyarakat dalam melakukan PSN DBD secara rutin.

\section{DAFTAR PUSTAKA}

Aritonang, L. 2009. Peramalan Bisnis. Jakarta: Ghalia Indonesia.

Baroroh. 2013. Analisis Multivariat dan Time Series dengan SPSS 2. Jakarta: Elex Media Komputindo.

BPS Kota Surabaya. 2016. Banyaknya Hari Hujan dan Curah Hujan di Perak 1. Diakses dari http://surabayakota.bps.go.id/webbeta/ 
frontend/linkTabelStatis/view/id/200 (sitasi tanggal 6 Maret 2016).

Dinas Kesehatan Jawa Timur. 2013. Profil Kesehatan Jawa Timur Tahun 2013. Surabaya: Dinkes Jatim.

Direktorat Jenderal P2PL DepKes RI. 2011. Modul Pengendalian Demam Berdarah Dengue. Jakarta: Kemenkes RI.

Direktorat Jenderal P2PL DepKes RI. 2014. Informasi Pengendalian Penyakit dan Penyehatan Lingkungan. Jakarta: Kemenkes RI.

Hermawan, 2011. Perbandingan Metode BoxJenkins dan Holt-Winters dalam Prediksi Anomali Olr Pentad di Kawasan Barat Indonesia. Jurnal Sains Dirgantara, 9:1: 27-34. LAPAN.

Makridakis., Victor. 1999. Metode dan Aplikasi Peramalan. Jakarta: Erlangga.
Sungkar S. 2007. Pemberantasan Demam Berdarah Dengue: Sebuah Tantangan yang Harus Dijawab. Jakarta: Majalah Kedokteran Indonesia.

Thomas Suroso, dkk, ed. 2011 Pencegahan dan Penanggulangan Penyakit Demam Dengue dan Demam Berdarah Dengue, Terjemahan, WHO danDepkes RI, Jakarta.

Wei. 2006. Time Series Univariate and Multivariate Methods. $2^{\text {nd }}$ ed. United States of America: Pearson Education.

Wirayoga, M.A.. 2013. Hubungan Kejadian Demam Berdarah Dengue dengan Iklim di Kota Semarang Tahun 2006-2011. Semarang: Universitas Negeri Semarang.

World Health Organization. 2013.Dengue Haemorrhagic Fever. Diagnosis, treatment, prevention and control. Geneva: $2^{\text {nd }}$ edition. 